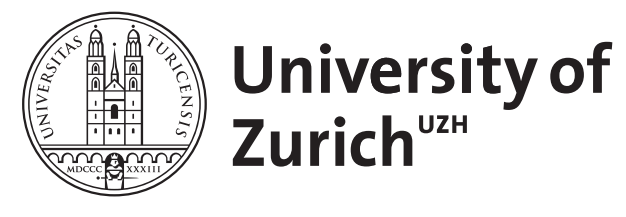

\title{
Source-Goal asymmetries in Ese Ejja
}

Vuillermet, Marine

\begin{abstract}
Ese Ejja (Takanan) is an endangered language spoken in the Bolivian and Peruvian lowlands. The paper examines the expression of Source and Goal in this Amazonian language and focuses on three types of Source-Goal asymmetries. The first asymmetry concerns the higher number of Goal adnominals than of Source adnominals. Linked to this morphological asymmetry, the second asymmetry is semantic: Goal adnominals display a $[ \pm$ human] distinction absent from Source markers. In addition, the two Goal adnominals are dedicated while the only adnominal that encodes Source may also encode Median. In fact, the unambiguous (and most frequent expression) of Source requires a biclausal strategy, which accounts for the third type of asymmetry, at the syntactic level. The discussion is based on firsthand data including both spontaneous and elicited data, mostly obtained with Trajectoire, a visual methodological tool designed to collect Path expression.
\end{abstract}

DOI: https://doi.org/10.1075/sl.18027.vui

Posted at the Zurich Open Repository and Archive, University of Zurich

ZORA URL: https://doi.org/10.5167/uzh-194485

Journal Article

Accepted Version

Originally published at:

Vuillermet, Marine (2021). Source-Goal asymmetries in Ese Ejja. Studies in Language, 45(1):235-275.

DOI: https://doi.org/10.1075/sl.18027.vui 


\title{
Source-Goal asymmetries in Ese Ejja
}

\author{
Marine Vuillermet \\ University of Zürich
}

\begin{abstract}
Ese Ejja (Takanan) is an endangered language spoken in the Bolivian and Peruvian lowlands. The paper examines the expression of Source and Goal in this Amazonian language and focuses on three types of Source-Goal asymmetries. The first asymmetry concerns the higher number of Goal adnominals than of Source adnominals. Linked to this morphological asymmetry, the second asymmetry is semantic: Goal adnominals display a $[ \pm$ human] distinction absent from Source markers. In addition, the two Goal adnominals are dedicated while the only adnominal that encodes Source may also encode Median. In fact, the unambiguous (and most frequent expression) of Source requires a biclausal strategy, which accounts for the third type of asymmetry, at the syntactic level. The discussion is based on firsthand data including both spontaneous and elicited data, mostly obtained with Trajectoire, a visual methodological tool designed to collect Path expression.
\end{abstract}

Keywords: Ese Ejja, Takanan, Source-Goal asymmetry, Goal-bias, biclausal Source constructions, perlative

\section{Source-Goal asymmetries in the literature: An overview}

A Motion event consists of four basic elements - Figure, (Fact-of-)Motion, Path and Ground expressions (Talmy 2000: 289). The Figure is the moving entity and the Ground the referent with respect to which the Figure moves. The Path followed by the Figure is a vector, consisting of a line in space that is continuous, delimited by two points, the Source and the Goal, and oriented between those points (Grinevald 2011:55). The Median is an intermediary point of the Path.

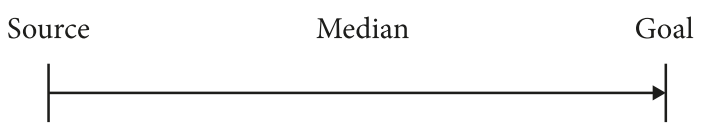

Figure 1. Path of motion and its different points 
The paper focuses on the expression of Source and Goal in the Amazonian language Ese Ejja (Takanan). While Source and Goal seems to be on equal footing from a logical perspective, Ikegami (1987) was the first to discuss Source-Goal asymmetry (the Goal-over-Source principle in his terminology). Since then, a growing body of work has confirmed this asymmetry in different domains.

Experimental studies actually suggest a cognitive bias toward Goal. To cite only a few, Lakusta \& Landau (2005) found that (English-speaking) William syndrome-impaired children, matched-age children and adults all included Goal more frequently than Source in describing motion events in two different experimental tasks. Regier \& Zheng (2007) showed that speakers of Arabic, Mandarin Chinese and English made finer semantic distinctions at motion event endpoints, compared to event initial points. This bias has also been observed in psycholinguistic research both with younger subjects (Freeman et al. 1981) and speechimpaired adults (Ihara \& Fujita 200o).

In descriptive and typological linguistics, most previous works have focused on adnominals. ${ }^{1}$ Ikegami observed the following asymmetries: the possible substitution of Source markers by Goal markers (but not vice versa), the 'unmarkedness' of Goal compared to Source, and the possibility of a semantic shift from Source to Goal (but not the other way around). Bourdin's (1997) study focused on three parameters, namely the modal parameter, ('modal' features of a motion event in relation to its Goal more often grammaticalized than in relation to its Source, e.g. to/towards/up to vs. from); the configurational one (below vs. from below, etc.); and the orientational one (in many languages, the deictic verb GO is compatible with Goal PPs only, while the deictic verb come is often compatible with both).

More recently, two contributions have shown that even apparent symmetry in the adnominal inventory does not necessarily mean consistent symmetry in the system. For instance, Wan (Mande; Côte d'Ivoire) has no spatial adnominal specialized to a specific locative role (Source or Goal), but it has a higher number of motion verbs specialized in Goals (6) than in Source (4) (Nikitina 2009). ${ }^{2}$ A variety of Laz (Kartvelian; Turkey) displays an unexpected syncretism of the Source and Goal marker (motative case). Nevertheless, upon scrutiny, this syncretism

1. Adnominals is the English translation of the term Adnominaux proposed by Papahagi (2011). Within a functional approach of the expression of Path, "traditional categories like prepositions, postpositions, cases, etc., [are] not operable. [...] The functional category called 'adnominal' gathers] all elements that introduce the name of an entity to make it the Ground of a Path: relator nouns, adpositions (simple and complex), case affixes" (Papahagi 2011: 119).

2. With motion verbs that do not restrict to a particular type of locative argument, the correct semantic role is inferred from the interaction of contextual information and the verb's lexical entailments. 
does not give way to semantic symmetry between the two roles: in context-free elicited utterances, speakers have a strong preference to interpret motative case as a marker for an allative spatial relation (Kutscher 2010). On a sample of 16 languages, Kopecka \& Ishibashi (2011) also emphasized the importance of not only looking at adnominals, but at the whole system available in a given language, showing some cases of symmetry. If a number of studies show a clear bias toward the Goal in both language and cognition, the diversity of languages investigated so far is still limited and needs to be explored in order to fully understand the phenomenon of Source/Goal asymmetry at different linguistic levels.

The present study is the first exploration of the Source-Goal asymmetry in Ese Ejja, an Amazonian language spoken in Bolivia and Peru. ${ }^{3}$ The language confirms the tendency already observed in other languages, and displays asymmetries at the morphosyntactic and syntactic level, giving way to higher semantic specification biased towards Goal. Section 2 presents the language and the data specifically collected for the purpose of this study, and gives an overview of the morphosyntactic inventory of the spatial expression in Ese Ejja. Sections 3 and 4 respectively address the morphological and the syntactical encoding of the Ground; both sections conclude in a summary of the observed asymmetries.

\section{The Ese Ejja language and the data}

\subsection{The speakers and their language}

Ese Ejja (Pano-Takanan) is an Amazonian language spoken by around 1,500 people in Bolivia and Peru. The language divides into 3 variants: Sonene (Peru and Bolivia) and Madidi (Bolivia only) are two close variants, while Baawaja (Peru only) is more distinct. The latter variant has very few speakers (a small dozen of elder people) and is not examined in this paper. Sonene and Madidi Ese Ejja are spoken on a daily basis in most villages. The generational transmission is threatened in some communities, but particularly well preserved in the Bolivian communities of Genechequía (Sonene variant), Portachuelo Alto (Sonene) and Bajo (Madidi). The dominant language, Spanish, is nevertheless also spoken on a daily basis when interacting with non-Ese Ejja people.

3. This work results from research within the program Trajectoire (Fédération de Typologie et Universaux, CNRS, 2007-2012), and more specifically as a member of the (a)symmetry axis led by Anetta Kopecka and Miyuki Ishibashi (see e.g. Kopecka \& Ishibashi’s 2010 guide) within the research program. 


\subsection{Methodology}

The 'Trajectoire corpus', henceforth Traj, is the main source of data for this paper: it consists of 477 Path sentences, recorded by nine Ese Ejja speakers who visualized a stimulus set called Trajectoire (Ishibashi et al. 2006). It consists of 55 Path video clips targeting the elicitation of Source, Median and Goal Grounds (mixed up with 19 fillers to distract speakers from our research goal, the collection of Path expression). Designed to be accessible to people from non-WEIRD societies, ${ }^{4}$ Trajectoire has proved to be an efficient tool in the assessment of the Source-Goal asymmetries (see Ishibashi 2015 and Vuillermet \& Kopecka 2019 for a detailed description and evaluation of the material). Ese Ejja speakers were at ease commenting the videos and most speakers produced utterances similar to naturally occurring ones in the rest of my corpus (Vuillermet 2018).

Trajectoire allowed collecting not only relevant expressions of the different portions of Path but also expressions absent from more spontaneous narratives. The morphosyntactic inventory already attested in the rest of my corpus was present in Traj, as well as less frequent expressions like a Source specified for its topological relation to the Ground ('from the top of X'). Note that the frequency rates obtained with Traj are of a very different nature from the statistics from large natural corpora. For instance, Stefanowitsch \& Rohde (2004) showed the prominence of Goal expression in a corpus of North American News. On the other hand, Traj is based on video-clips targeting a relatively balanced number of Path portions (32.8\% of Goal, 37.3\% of Median and $29.9 \%$ of Source Grounds). The proportion of the Path portions the consultants produced is relatively balanced too: $34.8 \%$ of Goal Grounds, $30.0 \%$ of Median Grounds and $27.1 \%$ of Source Grounds, to which must be added $8.1 \%$ of various undetermined Grounds, as summarized in Table 1.

I used the 3 distinct versions of Trajectoire in order to minimize possible routine effects. I faced two main issues with the use of the DVD. The first was a technical issue: two speakers did not view the whole set of video-clips and therefore produced a reduced number of sentences ( $c f$. the last two columns of Table 14). In addition, two speakers produced unexpected Path sentences: they hardly mentioned any Grounds, and one of them used the default verb poki- '(go,) move' to describe almost all video-clips, except when manner was marked (e.g. when the Figure was running or jumping). Consequently, their production is little represented in the paper. Detailed information on the consultants is available in Table 13 in the Appendix (variant spoken, age and gender). The variations between speakers in the strategies they use to encode the Grounds are listed in

4. For "Western Educated Industrialized Rich and Democratic" (Henrich et al. 2010). 
Table 1. Distribution of the encoding of the Grounds

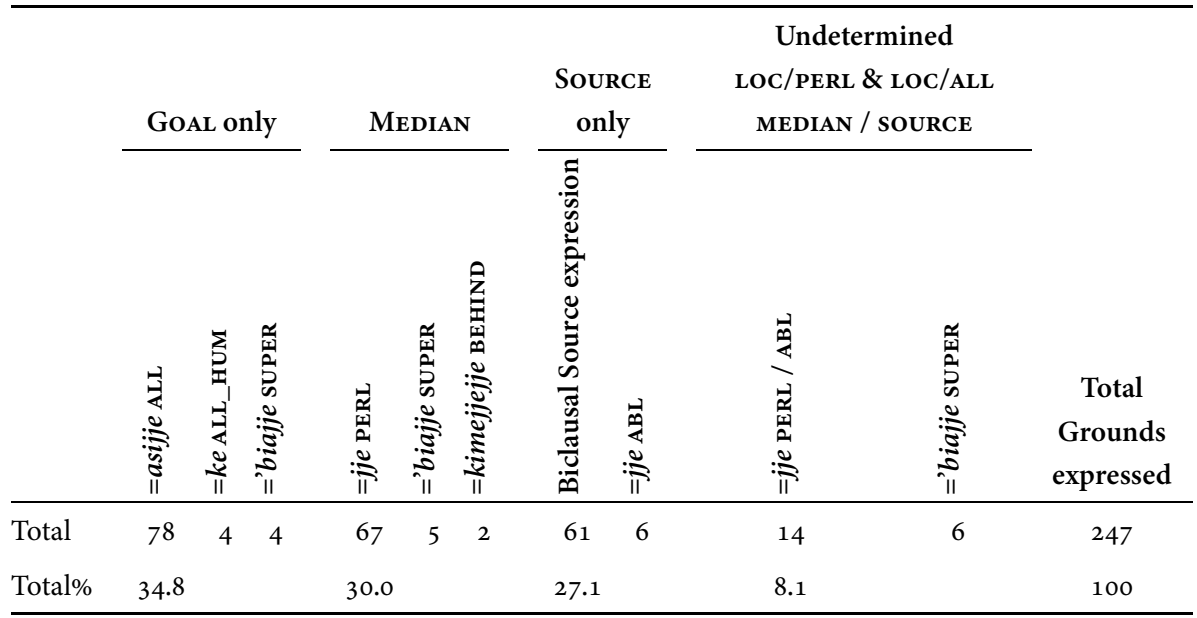

Table 14, also in the Appendix: they seem to be the result of individual strategies rather than reflect a specific language variant or community. The next section presents relevant information of the Ese Ejja grammar.

\subsection{Essentials of Ese Ejja grammar}

\subsubsection{General overview}

The constituent order in Ese Ejja main clauses is free in the sense that verb and arguments can appear in any order without any additional marking. When pragmatically neutral they tend to be verb-final, as illustrated in (1a-b). By contrast, dependent clauses are consistently verb-final, as will be observed for instance with the biclausal expression of Source.

Ese Ejja is an ergative language: the Agent is obligatory marked by an ergative marker $=a$; if the Agent is a 3 rd person, then the verb is also indexed with the suffix - $k a$, as illustrated in (1a). The Object (Theme or Recipient) remains unmarked, just like the single argument $S$ in ( $1 \mathrm{~b}$ ). To highlight the difference with the ergative marker, the absolutive arguments are exceptionally marked with a zero marker in (1a-b).

(1) a. Agent marking

E-pona $=\boldsymbol{a} \quad k w i i j j i=\emptyset$ weshe $=\emptyset \quad k i a-k a-a n i$.

NPF-woman=ERG man=ABS banana_sp=ABS give-3A - PRS

'A woman is giving a man a banana.'

$\{\text { Traj o11_Sap }\}^{5}$

5. All Ese Ejja data from Traj are annotated with a code like ' $\{$ Traj 005_Sap\}', which refers to the fifth scene of the DVD Trajectoire, uttered by the speaker Javier Monje Santa Cruz (aka. 
b. Single argument marking

E-pona $=\varnothing \quad$ jja-ja'be-ki-ani.

NPF-woman=ABS MID-comb-MID-PRS

'A woman is combing herself.'

\{Traj 019_Nil\}

Besides the ergative $=a$, Ese Ejja has 15 enclitics, which mark non-core arguments. As they all primarily mark the nominal sphere, I will refer to them as "adnominals" (Papahagi 2011; see fn. 1). Some encode non-spatial relations like the comitative $=$ nijje, and most of them encode spatial relations like the allative $=(w \sim y)$ asijje. The full list of the nine spatial adnominals is given in Table 3 and commented in the next section on the Ese Ejja spatial resources (Section 2.3.2.).

Ese Ejja is a mildly polysynthetic language: the verb paradigm consists of 14 slots, but person indexation is limited to 3 rd person Agent. Main clause (finite) verbs minimally consists of two to three morphemes: a root, an indexation marker if 3 rd person Agent, and a tense/mood marker (see the slots in bold in Table 2). As will be discussed in the next section, only posture verbs are an exception in the present tense (they remain unmarked for tense). Many dependent clauses have not fully inflected verbs, like the biclausal expressions of Grounds presented in this paper.

Table 2. Basic structure for inflecting verb (revised version of Vuillermet 2012a, 366)

$\begin{array}{lllllllllllllll}-3 & -2 & -1 & 0 & +1 & +2 & +3 & +4 & +5 & +6 & +7 & +8 & +9 & +10 & +11\end{array}$

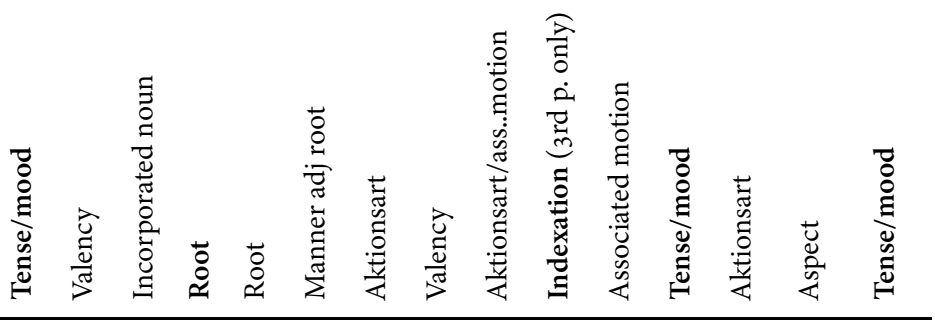

The following section accounts for the semantic elements most frequently expressed in Ese Ejja motion events, and for their distribution in the nominal and verbal sphere.

Sapaiai). Other sources used in the paper are variously labelled: \{fieldnotes\}, \{traditional narratives\}, \{spontaneous narratives\}, the two stimuli \{Bowerman \& Pederson's (1992)\} and Mayer's (1969) $\{$ Frog story $\}$, as well as elicited or volunteered sentences. 


\subsubsection{Spatial resources in Ese Ejja}

Spatial information in Ese Ejja can be very dense: in (2), four morphemes out of six give spatial information, and are found in both the nominal and verbal spheres.

(2) Mei='biajje neki-sowa-ki-naje. stone $=\mathbf{O N}$ (TO) stand-go_up-Go_To_V-PST

'He went up onto a stone (standing).'

$\{$ Frog/055_'Baw $\}$

In (2), the nominal sphere has the adnominal ='biajje, which encodes the resulting topological relation 'on(to)' between the Figure and the Ground, but not the Path. It is the verbal sphere that contains the most diverse spatial information: the first three verbal morphemes all convey spatial information and belong to three distinct slots (see Table 2). The first morpheme neki- 'stand' belongs to the subset of posture verbs. It forms a compound verb with the second morpheme, the intransitive Path verb sowa- 'go up', to indicate the posture of the Figure moving up. The third morpheme $-k i$ 'GO TO DO' is an 'associated motion' suffix, i.e. it associates a motion meaning to the verb it attaches to. ${ }^{6}$ Adnominals, Posture verbs and Path verbs are examined in turn in the next sections.

\subsubsection{Spatial adnominals}

Table 3 lists the nine spatial adnominals available in Ese Ejja according to their (former) morphological complexity: the first three are monomorphemic, while the next five end in =jje (cf. the perlative =jje) and the last one ends in =jo (cf. the locative $=j o$ ). The morphologically complex ones cannot be parsed synchronically, though =jakajjajje 'behind' certainly comes from the e-noun (e-)jakajja 'shoulder blade'.

Section 3 will show that the Ese Ejja adnominals are semantically heterogeneous: some are dedicated to one portion of Path only, while others can encode several Path portions. Some are only available to encode Grounds in either static or dynamic motion events, while others are available to Grounds of both subtypes. Some assign a specific topological relation between the Figure and the Ground.

6. See Vuillermet (2012a Chapter 12; 2012b, 2013) for a detailed accounts of the associated motion morpheme in Ese Ejja, and Guillaume (2016) for a recent typological account of such morphemes in South America. Such morphemes are actually part of the morphosyntactic inventory of the spatial expression, but are not discussed in this paper, as they are of little relevance for the expression of Source and Goal. 
Table 3. Spatial adnominals

\begin{tabular}{ll}
\hline Monomorphemic & $=j o$ \\
1. 'LOCative' & $=j j e$ \\
2. 'PERLative' & $=k e$ \\
3. 'ALLative_HUMan' & \\
=jje-based & $=$ asijje \\
4. 'ALLative' & $=$ 'biajje \\
5. 'ON(TO)' & $=$ =ipajje \\
6. 'BELOW' (contact) & $=$ kimejjejje \\
7. 'BEHIND, OPPOSITE SIDE' (no contact) \\
8. 'BEHIND' & $=$ jakajjajje \\
=jo-based & \\
9. 'NEAR' & $=$ pejjejo \\
\hline
\end{tabular}

\subsubsection{Posture verbs in the Ese Ejja grammar}

Posture verbs (henceforth PVs) are omnipresent in the language (Vuillermet 2009, 2012a: Chapter 14) and participate in the expression of motion in various ways. An overview of the many functions of the Ese Ejja PVs is thus relevant here. The PV set consists of four stative lexemes listed in Table 4, along with their dynamic (e.g. 'sit down', 'stand up') and causative (e.g. 'sit X', 'stand X', ...) counterparts.

Table 4. Posture verbs

\begin{tabular}{|c|c|c|c|}
\hline & Stative & DyNamic & Causative \\
\hline 1. 'be sitting' & ani- & ani-'oke- & iya- \\
\hline 2. 'be standing' & neki- & neki-sowa- & nekia- \\
\hline 3. 'be lying' & jaa- & jaa-'oke- & wana- \\
\hline 4. 'be hanging, floating' & 'ba'e- & 'ba'e-sowa- & 'ba'ewana- \\
\hline
\end{tabular}

For the sake of consistency, I will gloss the stative PVs 'sit', 'stand', 'lie', and 'hang'.

The four PVs form a subset of verbs on semantic and morphosyntactic grounds. First, their causative counterpart does not result from the combination of the root plus the general causative marker -mee (cf. last column in Table 4). Second, the PVs are the only verbs with no morphology for the present tense (ani 
(sit.PRs) 's/he sits / is sitting' vs. taaa-ani (shout-PRs) 's/he shouts / is shouting', compared to (ani-naje (sit-PAs) 's/he sat' vs. taaa-naje (shout-PAs) 's/he shouted'). Diachrony explains this morphological oddity: the four PV roots are the lexical origins of the two sets of imperfective and present markers listed in Table 5.

Table 5. Aspect and tense markers grammaticalized from posture verbs

\begin{tabular}{|c|c|c|c|c|c|}
\hline \multirow[b]{2}{*}{1 . } & \multirow{2}{*}{$\begin{array}{l}\text { ORIGINAL PV } \\
\text { ani- }\end{array}$} & \multicolumn{2}{|c|}{ IMPERFECTIVE MARKER (Slot + 10) } & \multicolumn{2}{|c|}{ Present MARKer $($ Slot +11$)$} \\
\hline & & $-a n i$ & '(sit.)IPFV' & $-\operatorname{ani}(a)$ & '(sit.)PRs”* \\
\hline 2. & neki- & $-n e k i$ & 'stand.IPFV' & $-(e) k i$ & 'stand.PRs' \\
\hline 3. & jaa- & $-j a a$ & 'lie.IPFV' & $-j a a$ & 'lie.Prs' \\
\hline 4. & 'ba'e- & -'ba'e & 'float.IPFv' & -'ba'e & 'float.PRs' \\
\hline
\end{tabular}

* Only-ani '(sit.)PRs' and -ani '(sit.)IPFv' have their semantic bleached in most cases, and their translation is therefore in parenthesis. The six other markers systematically keep their posture semantics, e.g. taaa-ki 'he is shouting standing', taaa-jaa 'he is shouting lying', taaa-'ba'e 'he is shouting hanging'.

(As will be discussed in Section 4, the imperfective markers are obligatory in some biclausal expressions of Grounds). Moreover, PVs also:

i. $\quad$ take part in various basic clause structures; ${ }^{7}$ the Basic Locative Construction illustrated in $(3 \mathrm{a}-\mathrm{b})$ is particularly relevant as it constitutes the basis for the biclausal Source expression examined in Section $4 ;^{8}$

(3) a. Jikio 'basha eja=jo 'ba'e.

DEM spider net=LOC float.PRS

'This spider is (lit. floats) in (its) net.'

\{BowPed oo7_Kan\}

b. (...)'dokwei=ja sheana=jo oya neki-naje.

stag $=$ GEN horn $=$ LOC 3 ABS stand-PAS

'(He thought he had grabbed a branch, but instead) he was standing on the stag's horn.'

$\{$ Frog 057_Baw\}

ii. often combine with the Path verbs 'oke- 'go.down' or sowa- 'go.up', not only to create the dynamic counterpart (e.g. neki-sowa- 'stand up', cf. Table 4), but also to form most Posture-Path verb compounds (neki-sowa(-ki)- 'go up' in Example (2)).

Note that the four PVs are phonologically and semantically remarkably well preserved in most uses, even as tense and aspect suffixes; their omnipresence, and the

7. They also appear in possessive, existential, and copula constructions.

8. The Basic Locative Construction is the construction that occurs in response to a question of the kind 'where is X?' (see e.g. Levinson 2003). 
quasi absence of semantic bleaching and phonological erosion reflects the cognitive importance of the expression of posture in Ese Ejja.

\subsubsection{Path \& deictic verbs}

The four basic Path verbs represent a specific class on morphosyntactic grounds. Their basic form is intransitive: their transitive counterpart results from the addition of a (no longer productive) transitivizer $a$, and they are bound forms that attach to the main verb, most often a PV. Semantically, they further subdivide into directional (Path) verbs and boundary-crossing ones.

Table 6. Intransitive Path verbs and their dependent transitive counterparts

\begin{tabular}{|c|c|c|}
\hline & INTRANSITIVE & Transitive \\
\hline 1. 'go up' & sowa- & -sowa- \\
\hline 2. 'go down' & 'oke- & -'okia- \\
\hline 3. 'go in' & no'bi- & -no'bia- \\
\hline 4. 'go out' & kwaya- & -kwaya- \\
\hline
\end{tabular}

The verb yejje- 'cross X' also expresses Path but, unlike the four basic Path verbs, it never combines with posture verbs. More importantly, its basic form is transitive, and its intransitive counterpart (jjaejjeki- 'cross') is a derivation with the general middle marker jja-...-ki. The deictic Path verbs poki- 'go' and poe- kwe- 'come' also express Path but do not display specific morphosyntactic features either.

\subsubsection{Overview of the expression of Source and Goal}

The most prototypical way to express a 'simple' Goal - i.e. when the topological relation with the Ground is not specified - is to use the Goal adnominal $=(w \sim y)$ asijje 'allative.'

(4) Prototypical Goal expression

a. Akwi=yasijje poki-ani.

tree $=$ ALL go-PRS

'She is going to the tree.'

$\{$ Traj 061_Soo\}

b. Towaa-ani, ena=wasijje

jump-PRs water $=\mathbf{A L L}$

'He is jumping... into the water.'

\{Traj 064_Mil\}

9. It has two phonetically conditioned allomorphs: =yasijje in front of [i] and =wasijje in front of $[\mathrm{o}]$ and $[\mathrm{a}]$. 
The Source may be expressed in a similar way with an adnominal phrase marked by $=j j e$, or with a biclausal construction. The adnominal $=j j e$ is a general perlative rather than a specific ablative. It can display an ambiguous reading between a Median and a Source Ground as in (5).

(5) Tata $=$ jje kwaya-ani.

foliage $=$ PERL go_out-PRS

'He is going out through / of the foliage.' \{Traj 027_vie\}

The biclausal construction expressing Source is much more frequent. It consists of a main motion verb (poki- 'go' and towaa- 'jump') and also involves a nonfinite Basic Locative Construction (cf. ( $3 \mathrm{a}-\mathrm{b})$ ) which is relativized, as illustrated in $(6 a-b)$.

(6) Prototypical Source expression
a. E-pona [shijje-tata=jo neki $](=\varnothing)$ poki-ani. NPF-woman corn-inside $=$ LOC stand.NF $(=\mathrm{ABS})$ go-PRS 'A woman is going (out) from the cornfield.' (Lit. A woman, standing in the field, is going.)
b. $[$ E-iyo $=$ jo neki $](=\varnothing)$ towaa-ani. NPF-hill=LOC sit.NF(=ABS) jump-PRS 'He is jumping from the hill.' (Lit. Standing on the hill he's jumping.) \{Traj 038_Nil\} \{Traj 064_Soo\}

This section has reviewed key features of the Ese Ejja language, focusing on the main elements of the expression of motion events - verbs and adnominals - to shed light on the data to be scrutinized below in search of Source-Goal (a)symmetry. The next section examines the adnominal encoding of the Ground, and Section 4 subsequently presents the syntactic expression of Grounds with biclausal constructions.

\section{The adnominal encoding of the Ground}

This section presents the five spatial adnominals attested in the Traj corpus for the encoding of Grounds and shows that they are semantically heterogeneous. The first four sections examine in turn the relevant parameters in the semantic information encoded in the adnominals: the portion(s) of Path (Section 3.1), the Ground types (Section 3.2), the topological relation between the Figure and the Ground (Section 3.3) and the motion component (Section 3.4) - cf. MOVE vs. BE.LOC in Talmy's (2000) typology. The last section summarizes the asymmetries. 


\subsection{Path portion}

Two spatial adnominals encode one specific path portion: the allative =asije and the human allative $=k e$ (Section 3.1.1). The other markers are less specific in that they can mark several portions of Path: the perlative =jje prototypically marks a Median Ground, but it can also mark a Source Ground (Section 3.1.2). The other two, ='biajje 'on(to)' and =kimejjejje 'behind' can alternatively mark a Goal or a Median Ground (Section 3.1.3).

\subsubsection{Specific Path portion: Goal only}

Two adnominals encode the Goal: =asijje 'ALL' and =ke 'HUM.ALL', illustrated in (7a) and (7b) respectively. (Their specialization for one Ground type [ \pm HUMAN] is discussed in Section 3.2.)

(7) a. Owe e-sho'i poki-naje akwi=yasijje.

one NPF-child go-PST tree $=\mathbf{A L L}$

'A child went towards the tree.'

$\{$ Frog 042_'Baw $\}$

b. Poki-je-o'oya pia 'dejja=ke.

go-FUT-AGAIN other man=ALL_HUM

'He is going to the other people again.'

$\{$ Traj 068_Sil\}

As a consequence of their specific semantics, the verbs occurring with the two allatives are mostly Path verbs encoding a translational motion like poki- 'go' in (7a-b), or Path or Manner verbs combined to an Associated Motion morpheme that emphasizes the translational motion as in $(8 \mathrm{a}-\mathrm{b})$.
a. Ekwana no'bi-ki-ani
e'bio=wasijje.
1EXCL.ABS go.in-GO_TO_V-PRS forest=ALL
'We go into the forest.'
b. $O=k e \quad$ 'besa-je'be-ani.
3=HUM.ALL SWIm-GO_BACK_VING-PRS
'(The dog) is swimming back to him.'

\{Trad. narr./Ekw.005_Koj\}

The human allative is infrequent (4 occurrences in Traj, and 3 in spontaneous texts) and only attested with such verbs. The allative =asijje also occurs with Manner verb like towaa- 'jump' in (9a) which does not specify whether the motion is self-contained or translational; displacement is entailed thanks to the presence of the adnominal. Interestingly, the allative =asijje happens to occur with (nonmotion) activity verbs, as in (9b). Here, it is thus only the adnominal that encodes the motion to a Goal, translated with the verb ir 'go' in the Spanish translation of (9b). 
(9) a. Towaa-ani ena=wasijje.

jump-PRS water $=\mathbf{A L L}$

'He is jumping into the water.'

b. 'Daki=kwana a'a pauro=wasijje tajja-jji miya=enei.

$\{$ Traj 064_Mil\}

clothe $=\mathrm{PL} \quad \mathrm{PROH}$ spring $=\mathrm{ALL} \quad$ squeeze-PROH $2 \mathrm{ERG}=$ alone

'Don't go to do the laundry at the spring.' $\quad$ \{Spont. narr./creo61_Soo\}

(From Spanish 'no vas a ir a lavar ropa al pauro solita')

In brief interactions, when greeting someone on one's way, speakers frequently just mention the Ground with no verb. Example (10) is the answer to a visitor who had just arrived at a woman's place and asked for her.

(10) $B a \tilde{n} o=$ wasijje $=p a$.

restroom $(\mathrm{SP})=\mathbf{A L L}=\mathrm{REP}$

'She said (she went) to the restroom.'

$\{$ Field $\}$

The allative $=$ asijje also infrequently occurs with sensory verbs to express a fictive Path, where the voice or the look reaches a Goal: 'shouting into the tree hole' (jjani-'dojjo=wasijje 'hole-inside=ALL') or 'looking (for the frog) into the boot' (zapato-'dojjo=wasijje 'boot(SP)-inside=ALL').

In terms of frequency in Traj, the adnominal =asijje mostly occurs with the Path verb no'bi- 'go' combined to the Associated Motion morpheme - $k i$ 'go to V' (42 tokens), with the (deictic) motion verb poki- 'go' (13), and with the mannermotion verb towaa- 'jump' (9). Other much less frequent verbs (1 to 2 tokens) are mostly Path verbs, often in combination with the Associated Motion morpheme $-k i$ 'GO TO DO'. My spontaneous corpus attests 107 occurrences of the allative $=a s i$ jje with 40 verbs. It mostly occurs with the (deictic) motion verb poki- 'go' (33), followed by the centripetal verb poe- kwe- 'come' (9), not attested in Traj. Path verbs in combination with the Associated Motion morpheme $-k i$ 'GO TO DO' are also frequent.

The human allative $=k e$ behaves in a similar way except for one difference discussed in Section 3.4. The two allatives stand in sharp contrast to the other spatial adnominals described in the next two sections.

\subsubsection{Several Path portions: Median or Source}

The adnominal =jje can encode two distinct portions of Path, the Source or the Median. 
(11) a. Source

E-pona kwaya-io-ani shijje-iye=jje eshaja me-jji.

NPF-woman go_out-TEL-PRS corn-field=PERL basket hand-ADJV

'A woman is coming out of a cornfield with a basket in the hand.'

\{Traj 038_Vie\}

b. Median

Poki-ani kia-wesha ejiojji=jje.

go-PRS APF-far path=PERL

'They are going far away by / along the path.'

$\{$ Traj 046_Sil $\}$

The perlative =jje has a very broad range of meanings, also attested for the Cavineña cognate $=e k e$ :

Its most central meaning appears to be perlative, i.e., 'through (a place)'. Other spatial meanings include ablative, i.e., 'from (a place)' and adhesive, i.e., 'along a place. The postposition =eke can also have non-spatial meanings. For example, it can be used to express a vehicle, i.e., 'on/by way of'. It can finally have temporal and other more abstract uses.

(Guillaume 2008:533, my emphasis)

The distinct functions of $=j j e$ and their exact distribution in Traj are illustrated in Table 7 . The adnominal $=j j e$ is glossed perlative as the Median is clearly the primary function of $=j j e$ with 67 clear cases out of 91 occurrences. Moreover, three speakers never used it to express the Source (Eli, Nil \& Sap).

Table 7. Distribution of the functions of $=$ jje 'PERL' per speaker

\begin{tabular}{lccccccccccc}
\hline & Eli & Lev & Sil & Zen & Nil & Sap & Soo & Mil & Vie & Total & Total \% example \\
\hline MEDIAN & 1 & 9 & 11 & 12 & 7 & 7 & 7 & 1 & 12 & 67 & $73.6 \%(12)-(13)$ \\
MEDIAN-SECUtIVE & 1 & - & - & - & - & 1 & - & - & 3 & 6 & $6.6 \%(14)$ \\
SOURCE & - & - & - & - & - & - & 1 & 1 & 3 & 4 & $4.4 \%(15)$ \\
UNDETERMINED & - & 2 & 1 & 3 & - & - & 6 & 1 & 1 & 14 & $15.4 \%(21)$ \\
Med/SOURCE & & & & & & & & & & & \\
Total & $\mathbf{2}$ & $\mathbf{1 1}$ & $\mathbf{1 2}$ & $\mathbf{1 5}$ & 7 & $\mathbf{8}$ & $\mathbf{1 4}$ & 3 & $\mathbf{1 9}$ & $\mathbf{9 1}$ & $\mathbf{1 0 0 \%}$ \\
\hline
\end{tabular}

The examples below illustrate the different functions in turn: perlative ('through, across, via' in Example (12) and 'past' in Example (13)), Mediansecutive (or adhesive) in (14), and Source in (15). 
(12) Perlative - 'through, across, via' (perlative according to Hagège 2010:261)
a. Po'aeki-eki
e'bio=jje.
have_a_walk-stand/PRs jungle=PERL

'She is having a walk through/in the jungle.'

\{Traj 027_Sil\}

b. Poe-io-ani meikaa=jje.

come-TEL-PRS stone_area $=$ PERL

'He is arriving via the rocky path.'

$\{$ Traj 027_Sil $\}$

(13) Perlative - 'past' (aka. prolative)

Kwajikwaji-ani mei=jje.

run-PRS stone $=$ PERL

'He is running past the stone.'

\{Traj 042_Vie\}

(14) Secutive (Hagège 2010: 261) aka. Adhesive (Guillaume 2008:533) - 'along'

E-sho'i kwajikwaji-ani meshijaji-sawa=jje

NPF-child run-PRS sand-side $=$ PERL

'The child is running along the shore.'

\{Traj 034_Sap\}

(15) Ablative

a. E-pona kwaya-'io-ani shijje-iye=jje eshaja me-jji.

NPF-woman go_out-TEL-PRS corn-field=PERL basket hand-ADJV

'A woman is coming out of a cornfield with a basket in the hand.'

\{Traj 038_Vie\}

b. Jaasowa-ani ena-sawa=jje.

(lie)go_up-PRS water-edge $=$ PERL

'She is going up from the riverbank.'

$\{$ Traj 074_Mil\}

Finally, just like the Cavineña perlative, Ese Ejja =jje also displays a non-spatial meaning like the median in 'bishe=jje 'by canoe' or ejiojji=jje 'on foot'.

The wide range of spatial semantics covered by the marker =jje requires cues to obtain the right interpretation: the motion verb, the Ground, and the context may all play a role. Utterances with non-deictic Path verbs seem to favor a Median interpretation. The boundary-crossing verbs $(y)$ ejje- 'cross, going through X' and $n o$ 'bi- 'enter' seem to allow the Median reading only. ${ }^{10}$ In (16a-b), Figures are walking over a bridge to cross a river and going through a thick bush; in (17a-b), Figures are entering (through) dense vegetal areas.

10. The transitive verb yejje- 'cross $\mathrm{X}$ ' (see its intransitive counterpart jjaejjeki- in (16a-b) is probably the origin of the perlative $=j j e$. Heine $\&$ Kuteva (2002:230) report such grammaticalization paths in Greek and Ewe (but acknowledge that the pathway still requires documentation) and classify this "as an instance of more general process whereby verbs denoting location or motion serve as structural templates to express relational (adpositional) concepts”. 
(16) a. Oya jja-ejje-ki-ani akwi e-wana=jje 3ABS MID-cross-MID-PRS tree RES-lay=PERL

'He is crossing a bridge.'

\{Traj 050_Soo\}

b. Tata kia-moo-nee=jje jja-ejje-ki-ani

foliage APF-thick-very=PERL MID-cross-MID-PRS

'He is going through a very thick bush.'

\{Traj 026_Vie\}

(17) a. Akwi-tata=jje no'bi-ki-ani

tree-foliage=PERL go.in-GO_TO_V-PRS

'He is going to enter (through) the foliage.'

b. E'bio=jje no'bi-ki-ani

\{Traj 056_Vie\}

jungle=PERL go.in-GO_TO_V-PRS

'He is going to enter (through) the forest.'

\{Traj 026_Lev\}

However, the other boundary crossing verb kwaya- 'go out' allows for both the perlative and the ablative readings, as suggested by the two Spanish translations in $(18 \mathrm{a}-\mathrm{b})$. It is thus the context and/or the shared knowledge that will give the right cue.

(18) a. Kwaya-ani mei-wejja=jje.

go_out-PRS rock-hole $=$ PERL

'He is going out of the cave.' or 'He is going out through the cave.'

$\{$ Traj 028_Mil\}

(Translation into Spanish with the Median adnominal: 'sale por el hueco de la piedra')

b. Tata-'dojjo=jje kwaya-ani.

foliage-inside=PERL go_out-PRS

'He is going out of the forest.' or 'He is going out through the forest.'

\{Traj 028_Soo\}

(Translation into Spanish with the Source adnominal: 'está saliendo del monte')

Manner-of-motion verbs like po'aeki- 'have a walk', kwajikwaji- 'run' or jiojio'walk' seem to primarily associate with the Median portion, but the exact function of the perlative varies according to the Ground type (Aurnague et al. 1997; Aurnague 2004; Kopecka 2009):

i. object Grounds are "moved" past, i.e. they trigger a prolative reading, like the stone in (13);

ii. geographical areas can be "moved" along (secutive reading), like the shore in (14) or "moved" in/over (perlative reading) as in (19). 
(19) Geographical locations (large region) - Perlative 'move in/over'

a. Oya jiojio-je'be-ani sipone=jje.

3ABS walk-DO_RETURNING-PRS grass $=$ PERL

'She is walking back through the grass(field).'

b. Owe kwiijji'beka e-pona e'bio=jje po'aeki-eki.

$\{$ Traj 051_Zen\}

one man two NPF-woman forest=PERL have_a_walk-stand/PRS

'One man and two women are walking in the forest.'

\{Traj 041_Sap\}

The deictic verbs poki- 'go' and poe- 'come' are compatible with prolative and perlative readings too, but they seem to have an additional perlative reading 'through' with dense places.

(20) Dense places - Perlative '(go) through'

a. Shijje-iye=jje poki-ani eshaja me-jji.

corn-field=PERL go-PRS basket hand-ADJV

'She is going through a corn field with a basket in her hand.' Traj 069_Vie\}

b. Poe-je tata=jje.

come-FUT foliage $=$ PERL

'He is coming through the dense foliage.'

(man going out of the forest)

\{Traj 055_Mil\}

Example (21) shows that the same utterance (produced by the same speaker) can refer to fairly distinct situations. The pathway in \{Videoclip 048$\}$ is a road Ground crossed by the Figure, and walked along in \{Videoclip 070\}. ${ }^{11}$

(21) Ejiojji=jje poki-ani.

path=PERL go-PRS

'He is crossing a path.'

$\{$ Traj 048_Lev\}

'He is moving along a path.'

$\{$ Traj 070_Lev\}

In natural discourse, the context guides the listener to choose the correct reading, maybe supported by gesture and/or intonation. Also, an utterance with both an allative and a perlative marker may force the Source reading.

(22) Kwaya-ani mei-jjani=jje pia mei-jjani=yasijje

go_out-PRS rock-hole $=$ PERL other rock-hole $=$ ALL

no'bi-ki-o'oya-ani.

go_out-GO_TO_V-again-PRS

'He is going out of the cave (and) entering another cave.'

\{Traj 06o_Vie\}

11. In compliance with Bourdin's (1997) orientational parameter, the Go verb does not seem to allow for a Source reading if associated to the perlative marker. More work is required on this issue. Note that poki- 'go' is compatible with the biclausal Source expression, see Section 4. 
The next examples show that $=j j e$ can occur twice in an utterance - it then probably must encode two different functions, here an ablative and a perlative (or prolative); see also (29b).

(23) $M e i-{ }^{\prime} d o j j o=j j e \quad k w a y a-a n i$ ejiojji=jayojja=jje. rock-inside= $=$ PERL go_out-PRS path $=$ SML $=$ PERL

'She is going out of the cave by/through/along what looks like a path.'

\{Traj 022_Soo\}

\subsubsection{Several Path portions: Goal or Median}

Unlike the two allatives =asijje and $=k e$ (Section 3.1.1), but like the perlative marker =jje (Section 3.1.2), the two adnominals ='biajje 'above' and =kimejjejje 'behind' are used for different Path portions. They still differ from the perlative in two ways: first, they can encode either the Goal or the Median, not the Source (at least not directly, see Section 4). Moreover, and unlike all three other adnominals examined so far, they express specific topological relations. Among the five complex adnominals that specify topological relations (cf. Table 3 ), these are the only two attested in Traj.

The superessive ='biajje is much more frequent than =kimejjejje and is more detailed here. Table 8 sums up the frequency of each function of ='biajje in Traj and shows that it is primarily found in static motion events where it encodes Location (and Source when in a biclausal construction); this function is addressed in Section 3.4. It also frequently encodes the Median, and much more occasionally, the Goal.

Table 8. Frequencies of the distinct functions of the adnominal ='biajje 'on(to)' (47 tokens)

\begin{tabular}{lrl}
\hline Function & Tokens & see... \\
\hline Location Main Clause & 13 & Section 3.4 \\
LoCATION (SOURCE) Dependent Clause & 10 & Section 4 \\
MEdian (THROUGH) & 14 & Example (24)-(25) \\
AlLATIVE & 4 & Example (26) \\
Ambiguous (Loc\&Median) & 6 & Example (25a) vs. (26) \\
Total & 47 & \\
\hline
\end{tabular}

In the rest of the corpus, ='biajje mostly appears in answers to (static) pictorial stimuli (Mayer 1969; Bowerman \& Pederson 1992), and, unsurprisingly, exclusively encodes location. 
In descriptions of dynamic motion events of Traj, ='biajje unambiguously marks 14 Median grounds. The next examples illustrate various subfunctions with different Ground types, namely the perlative with places (a stone pathway and a bridge in Example (24)) or the prolative with objects (a tree in Example (25)).

(24) Median - Perlative 'move' over a road-like place

a. Kwiiji-sho'i mei='biajje jiojio-ani.

man-child stone $=$ ON(TO) walk-PRs

'The young boy is walking over a stone pathway.'

$\{$ Traj 076_Nil\}

b. Kwiijji-sho'i(...) puente='biajje po'aeki-eki.

man-child bridge(sP) $=$ oN(To) have_a_walk-stand/PRS

'The child is having a walk on a bridge.'

\{Traj 050_Zen\}

(25) Median - Prolative 'move' over an object

a. Towaa-ani akwi='biajje.

jump-PRs tree $=\mathbf{O N}(\mathbf{T O})$

'(The man) is jumping over the tree(log)'.

\{Traj 072_Sap\}

b. Kwajikwaji-ani akwi='biajje.

run-PRS tree $=\mathbf{O N}(\mathbf{T O})$

'(The man) is running over the tree $(\log )$.'

$\{$ Traj 072_Sil $\}$

Most occurrences involve manner of motion verbs. Occurrences with the Path verbs poki- 'go' (5) and poe- 'come' (1) are attested with only 3 speakers. These uses involve 'places' Grounds (road or large geographical locations) and have a perlative reading.

Goal Grounds marked by ='biajje only appear with the manner of motion verb towaa- 'jump', in the description of only two video-clips illustrated in (26). (One consultant produced (26a) and three produced (26b); others described the child as 'playing' or did not mention the Ground).

(26) Goal - Allative

a. E-sho'i towaa-ani mei='biajje.

NPF-child jump-PRS stone $=\mathbf{O N}$ (TO)

'The child is jumping onto the stone.'

\{Traj 062_Vie\}

b. Towaa-ani mei='biajje.

jump-Prs stone $=\mathbf{O N}(\mathbf{T O})$

'He is jumping onto the stone.'

\{Traj 063_Lev/Sil/Zen\}

Ambiguity could appear out of context: compare the allative reading in (26) 'onto a stone' and the perlative reading in (25a) 'over a log'.

The least frequent topological adnominal =kimejjejje 'behind' occurs two times (with the same speaker) in Traj, where it encodes a Median and a Goal Ground with the deictic Path verb poki- 'go, move', as illustrated in (27a-b). In 
the rest of the corpus, it occurs seven times to describe static motion events (see Section 3.4) to describe stimuli pictures or (staged) object manipulations.

(27) Median and Goal in Traj

a. Akwi=kimejjejje poki-ani.

tree $=$ BEHIND go-PRS

'He passes behind the tree.'

\{Traj 039_Vie\}

b. E-pona tata=kimejjejje poki-ani.

NPF-woman foliage $=$ BEHIND go-PRS

'The woman is going behind the bush.'

$\{$ Traj 057_Vie\}

To summarize, some adnominals in Ese Ejja are specific to one Path portion of a dynamic motion event, others are not. Only the expression of Goal has two dedicated adnominals, =asijje and $=k e$; that of Source has none. The perlative $=j j e$ either indicates the Median or the Source, and the topological adnominals ='biajje and =kimejjejje either the Median or the Goal.

\subsection{Ground types and topological relation}

\subsection{1 [ \pm human] Grounds}

Out of the five adnominals attested in Traj, only one is specialized in human Grounds: the human allative $=k e$. It can mark a group of persons as in ( $7 \mathrm{~b})$ or an individual as in (28).

(28) Kwiijji poki-ani e-pona=ke.

MAN go-PRS NPF-Woman=ALL_HUM

'The man is going to the woman.'

\{Traj 036_Sap\}

If the four other adnominals are to specify an area where a human is or does something, then a biclausal construction must be used (29). (See Section 4 for a discussion of the structure of these biclausal constructions). The biclausal construction refers to the area where the person is located, rather than more specifically to the person.

(29) a. Poki-ani e-pona-sho'i=ke, [e-pona-sho'i jaa]=wasijje. go-PRS NPF-woman-child=ALL_HUM NPF-woman-child lie.NF=ALL_HUM 'The man is going to the young woman, to where the young woman lies.'

\{Traj 036_Soo\} 
b. Owe e-pona jja-ejje-ki-ani puente=jje [kwiiji

one NPF-woman MID-cross-MID-PRs bridge(SP)=PERL man

neki]=jje.

stand.NF $=$ PERL

'A woman is crossing over the bridge, passing by (where) a man (is) standing.'

\{Traj 047_Sap\}

There is no corresponding human ablative, nor a human perlative.

\subsubsection{Topological relation}

Out of the five adnominals attested in the Traj data, only two, ='biajje '=on(to)' and =kimejjejje behind, specify the relation of the Figure to the Ground, i.e. encode their topological relation. As mentioned above, the two adnominals do not encode a specific Path portion, but can either encode the Goal or the Median.

The expression of the topological relation for the Source requires a biclausal construction as exemplified in (30).

(30) [Mei='biajje neki] towaa-ani.

STONE $=\mathbf{O N}(\mathrm{TO})$ stand jump-PRS

'He's jumping from the top of the rock (lit. standing on the rock, (he) jumps).'

\{Traj 034_Soo\}

\subsection{Dynamic vs. static motion events}

Talmy's (2000) definition of Motion Event includes static motion events like 'he is in the tree' and dynamic ones like 'he's going to the tree'. In Ese Ejja, only the allative marker =asijje exclusively marks the Ground of a dynamic motion event. The other markers can either mark the Ground of a static or of a dynamic motion event.

Examples (31a-b) and (32) contrast the allative =asijje 'ALL' with the locative =jo 'LOC' used with the same Grounds, akwi 'tree' and e'bio 'forest'.

(31) a. Owe e-sho'i poki-naje akwi=yasijje.

one NPF-child go-PST tree $=\mathbf{A L L}$

'A child went towards the tree'.

b. Ekwana no'bi-ki-ani e'bio=wasijje.

$\{$ Frog 042_'Baw $\}$

1EXCL.ABS go.in-GO_TO_V-PRS forest=ALL

'We go into the forest.'

\{Spont. narr./Ekw.005_Koj\}

(32) Ma e’bio=jo ani-ani-naje. Akwi=jo.

DEM forest=LOC sit-sit/IPFV-PST tree $=\mathbf{L O C}$

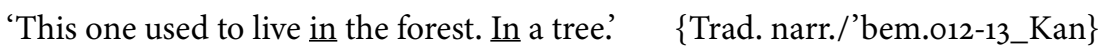


Because of their semantics, =asijje 'ALL' mostly occurs with motion verbs and =jo 'LOC' with stative or (non-motion) activity verbs. The only exception appears to be the stative PVs in what seems to be an idiomatic expression ojjaña meshi=asijje (all ground=ALL) 'in all countries' to refer to the existence of an entity all over the world, maybe to insist on how widespread it is.

(33) Peyo ojjaña meshi=yasijje $y$-ani.

VIPER all ground $=$ ALL PRES-sit

'There are vipers in all countries.'

\{Spon. narr./peyo48_Kan\}

Interestingly, Ese Ejja is the only Takanan language to distinguish Goal from location: the cognate of $=j o$ 'LOC' encodes either Goal or location in Cavineña (Guillaume 2008:522), Araona (Emkow 2006: 184-85), Takana (Guillaume 2014) and Maropa (Guillaume 2012).

There is no spontaneous use of $=k e$ to indicate location in the Ese Ejja corpus, which suggests that its primary function is to encode the Goal. Elicitation with two distinct consultants shows that $=k e$ can also mark human location, for instance when associated with stative PVs, as in (34a). It also appears with nonmotion verbs but it is rare ( 2 occurrences out of 68 in the whole corpus). The perlative then refers to a general location, an area (as opposed to a specific location encoded by $=j o$ ), as illustrated in ( $34 \mathrm{~b})$.
a. $\quad O j a=n a=k e=t i i$
neki.
3ABS $=$ mother $=$ ALL_HUM $=$ INTS stand.PRS
'He's always where his mother is.'
b. Ojaya jikio=jje lunar ani-naje
3GEN here=PERL mole sit-PAS

\{elicited\}

'He had a mole here (gesture on the part where the mole was).'

\{Spon. narr./'bajoo8_Soo\}

Table 8 had shown that in Traj, ='biajje is primarily found in static Motion Events where it encodes location (and Source); Examples (35a-b) illustrate the use of $=$ 'biajje and =kimejjejje in static Motion Events where they encode the location of the Figure.

(35) a. Sipone='biajje kawi-jaa.

grass $=\mathbf{O N}$ (TO) sleep-lie/PRS

'He is sleeping (lying) over the grass.'

\{Traj 002_Vie\}

b. Ojaya iñawewa 'dokwei-'ai=ja e-naa=kimejjejje neki. 3 GEN dog deer-big=GEN NPF-throat=BEHIND stand.PRS

'The dog stands on the other side of the deer's neck.' $\quad$ \{Frog 155_Kan\} 


\subsection{Summary of the asymmetries among adnominals}

As summarized in Table 9, Goal-biased asymmetries exists at four levels in the adnominal encoding of Source and Goal in Ese Ejja. At the morphological level, the language displays a larger adnominal inventory: four adnominals (can) encode the Goal, while only one can encode the Source. Such Goal-biased imbalance in the number of adnominal markers is common cross-linguistically, for example in German and Japanese (Kopecka \& Ishibashi 2011:140ff.).

Table 9. Adnominals found in Traj and their specificities according to the Path portion encoded

\begin{tabular}{lccccc}
\hline $\begin{array}{l}\text { Path } \\
\text { portion }\end{array}$ & $\begin{array}{c}\text { Overall } \\
\text { number of } \\
\text { markers }\end{array}$ & $\begin{array}{c}\text { Dedicated to a } \\
\text { specific } \\
\text { portion }\end{array}$ & $\begin{array}{c}\text { Ground type } \\
\text { specification }\end{array}$ & $\begin{array}{c}\text { Topological } \\
\text { specification }\end{array}$ & $\begin{array}{c}\text { Specialized in } \\
\text { dynamic motion } \\
\text { events }\end{array}$ \\
\hline Goal & 4 & + & + & + & + \\
Median & 2 & - & - & + & - \\
Source & 1 & - & - & - & - \\
\hline
\end{tabular}

The larger inventory is all the more remarkable in that Ese Ejja has no dedicated Source adnominal: two adnominals, =asijje 'allative' and =ke 'human allative', exclusively encode the Goal. The other three adnominals can encode the Median or the Goal (='biajje 'on(to)' and =kimejjejje 'on(to) the other side'), or the Source or (mostly) the Median (=jje 'perlative').

The Goal-biased asymmetry also involves the semantic granularity (cf. the modal asymmetries described by Bourdin 1997): the human allative $=k e$ is the only adnominal dedicated to a Ground type and it encodes a Goal Ground. There is no corresponding [+HUMAN] Source adnominal.

Interestingly, the perlative $=j j e$ is the most common Ground marker in Traj (91 tokens) if its multiple readings are not distinguished. If only the nonambiguous readings are considered ( 67 tokens), then the Median reading is the second most frequent Ground marker in Traj, after the general allative $=$ asijje ( 78 tokens). This ranking cannot be extrapolated to spontaneous speech: it should be kept in mind so that the results do not reflect natural frequency. However, such an overwhelming presence raises the issues of how Source-Goal asymmetry should be measured in languages like Ese Ejja where Source and Median can be expressed with the same marker.

Quite unexpectedly, the trisyllabic general allative =asijje seems to be morphologically more complex than the monosyllabic human allative $=k e$, the locative $=j o$ and the perlative-ablative $=j j e$, and even seems to be morphologically 
based on the latter. This unusual complexity contradicts Bourdin's (1997) observations: Source markers tend to be morphologically more complex than Goal markers and may be morphologically based on the (locative-)allative marker (cf. English under vs. from under the table). Just like the unexpected syncretism in the Ardeşen variety of Laz (Kutscher 2010) can be understood via diachrony, historical explanations elucidate why the Ese Ejja data contradicts the observed crosslinguistic tendency. The dedicated Goal marker is undoubtedly an innovation: the four sister languages Cavineña, Araona, Maropa and Tacana do not distinguish between Goal and location, and they use a general locative cognate with the Ese Ejja (specific) locative $=j o$. Supporting the innovation scenario, $=$ asijje very likely comes from a relator noun (e-)wasi 'toe' and the perlative =jje (cf. (e-)jaka 'back' $>$ =jakajje 'in/to the back of, behind'). The reason why =asijje would be based on the perlative/ablative $=j j e$ is probably linked to the innovation - the whole system may have shifted from one general spatial marker to two markers specified in location vs. Goal (see Vuillermet 2015 for more details). Section 4 now describes the biclausal construction, the most frequent expression of Source.

\section{Asymmetries in the biclausal encoding of the Ground}

While Goal-oriented events in Ese Ejja tend to be depicted in a single clause ('Figure moves to Ground'), the Source-oriented events are mostly expressed in two clauses (literally '[being at Ground], Figure moves' for 'Figure moves out of Ground'). Such biclausal expressions indeed account for $75.3 \%$ to $91 \%$ of all Source Grounds found in the Traj corpus. ${ }^{12}$ Kopecka \& Ishibashi (2011: 146) count it as a case of Source-Goal asymmetry in terms of "event sequencing" (séquençage d'événement) and also highlight that such constructions have not been considered in the Source/Goal asymmetry literature so far. They further suggest that biclausal expressions are interesting at two levels: if they are more complex at the syntactic level, they are also more informative as they may specify topological relations and/or the posture of the Figure.

Section 4.1 describes the prototypical (biclausal) expression of Source in Ese Ejja. Section 4.2. turns to the less frequent use of more specific adnominals (='bia$j j e$ 'ON(TO)' and =jje 'PERL' rather than $=j o$ 'LOC') to encode topological information. Section 4.3. argues that the posture verbs used in the biclausal strategy do not only denote the posture of the Figure, and thus do not really convey addi-

12. $24.7 \%$ to $9 \%$ are encoded by the perlative $=j j e$ : the exact number of Source Grounds encoded by $=j j e$ is unknown, because 14 tokens are undetermined for Source or Median (cf. Table 9). 
tional information compared to the more concise adnominals. Section 4.4 highlights that, unlike the dedicated allative =asijje, but like the other adnominals, the biclausal construction of Source is sensitive to the verbs it associates with. Section 4.5 reminds one that a biclausal strategy is also available to express Median and Goal but shows that it differs in many important ways from the Source biclausal expression. It also briefly discusses biclausal Source expressions cross-linguistically and emphasizes its high frequency and productivity in Ese Ejja, as it is the only unambiguous strategy to encode Source.

\subsection{The prototypical expression of Source}

In Ese Ejja, the most frequent expression of Source is a biclausal construction that consists of:

i. a dependent clause (DC) that is a relativized Basic Locative Construction (BLC);

ii. a main clause that displays a fully finite motion verb, and whose subject is the antecedent of the relativized BLC.

The DC is made of a Ground marked by an adnominal (the locative $=j o$ ) and a non-finite PV (cf. (3a-b) for main clause, finite BLCs). (The presence of the absolutive zero morpheme in (36) is commented further below.)

(36) a. $\quad[$ Enaojjo=jo jaa $]=\emptyset \quad$ meshi=yasijje neki-sowa-ki-'io-ani river=LOC lie.NF=ABS ground $=\mathrm{ALL}$ stand-go_up-GO_TO_V-TEL-PRS 'He is going up from the river to the ground.'

b. 'Dejja kwaya-'io-ani [tata-'dojjo=jo neki]=Ø. $\{$ Traj 031_Lev\} man(.ABS) go_out-TEL-PRS foliage-inside $=$ LOC stand.NF $=$ ABS 'A man is going out of the forest.'

c. E-pona kwaya-ki-ani [jjani-'dojjo=jo ani] $=\varnothing$. NPF-woman(.ABS) go_out-GO_TO_V-PRS hole-inside=LOC sit.NF=ABS 'A woman is going out of the cave.'

\{Traj 071_Sap\}

The intonation tends not to go down between the two clauses, but only at the end of the last clause, showing that the two clauses form one sentence together. As shown in the next section, independent BLCs and relativized Source BLCs differ in several respects: flexible word order vs. rigid verb final (all the relativized BLCs in the corpus are verb final), finite vs. non-finite PV and possible presence vs. necessary absence of the Figure. 


\subsubsection{Non-finiteness of the PV}

PVs in the (biclausal) expression of Source are non-finite. At first glance, they could be alternatively analyzed as being in the present tense, because it is the same form: in this paper, neki is either glossed as 'stand.NF' as in (36b) or 'stand.PRs' (as in Example (34a) or Example (35b)); see the section on the specificities of posture verbs in Section 1.3.2). Example (37) demonstrates that a PV in a (relativized) Source BLC must remain non-finite, i.e. unmarked for tense (or mood): consultants judge impossible the form ani-a=poa, marked with the remote past.
(37) Jamaya $=p a$, 'ba'e-poki- $a=p o a$
ma e-pona,
SO=REP hang;live-go/CONT-REM.PAS=REM.PAS DEM NPF-woman
'Bemashapona. [E'bio=jo ani]. ${ }^{\star}$ ani-a=poa
Sloth.woman jungle $=$ LOC sit.NF sit-REM.PAS $=$ REM.PAS
'That is the way (she) used to live this woman, the sloth-woman. (That) from the jungle.' (Lit. in the jungle sitting)
\{Trad. narr./'bemo49_kan\}

\subsubsection{Adnominal marking and absence of the core argument associated with the Source}

The transcription and gloss in $(36 a-c)$ exceptionally showed that the non-finite clauses are in fact "marked" by an absolutive zero morpheme, determined by the role of the Figure in the main clause (MC), a subject of an intransitive motion verb in all three examples. When Source biclausal constructions occur with transitive verbs, two contrasting markings are available to identify the argument to which the Source is linked. Examples (38a) and (38b) both describe the same scene in the Frog Story where the stag throws the boy into the water. In (38a), the Source BLC is marked with an ergative and is thus linked to the A argument: the BLC encodes the place from which the stag (A argument) performs the caused motion. In (38b), the Source BLC is marked with a zero morpheme and is thus linked to the $\mathrm{P}$ argument: the BLC encodes the Source from which the boy ( $\mathrm{P}$ argument) moves.
a. $\quad$ Eiyo='biajje neki $]=\boldsymbol{a}$
oya ena=wasije
hill=ON(TO) stand.NF=ERG 3sG water $=$ ALL
jia-'okia-jia-ka-naje.
throw-put.down-DO.X.AWAY-PAS

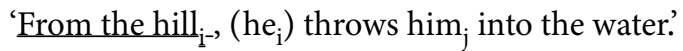
\{Traj 047_Vie\}
(or 'Standing on the hill, (he) throws him into the water') 
b. [Emakoo-'ao-'ao=jo oja=e-sheana='biajje ani] $=\varnothing$

cliff-big-big=on $\quad 3$ GEN-NPF-horn $=\mathrm{ON}(\mathrm{TO})$ sit.NF $=\mathbf{A B S}$

jia-towa-ka-'io-naje.

throw-horizontally=3A-TEL-PAS

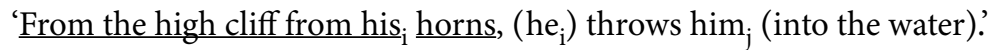

\{Frog 073_Soo\}

(lit. sitting on the high cliff on his $_{\mathrm{i}}$ horn, $\left(\mathrm{he}_{\mathrm{i}}\right)$ throws $\left(\right.$ him $\left._{\mathrm{j}}\right)$ into the water')

(Spanish: Del barranco alto en cima del cuerno de él lo botó al río.)

Note that the subject of the PV is necessarily co-referential with one core argument of the main clause, and necessarily left implicit in the DC.

The strategy of marking a DC with an adnominal is found elsewhere in the grammar, as illustrated by another type of relative clauses in (39a-b).

(39) a. Non-finite relative clause

... [ma nawoo jjeshe-jji]=a, ekwana jama=tii sosemá

RELZ fish buy-NMZ=ERG 1EXCL.ABS SO=INTS for.free

jia’okia-ka-naje.

bring.downriver-3A-PAS

'(the merchant, what's his name again,) the one who buys fish, brought us downriver just like that, for free.' $\quad$ \{Spont. narr./viao59_soo\}

b. Finite relative clause

Majoya iñawewa $=a$ shiye'ajja-ka-naje [ $m a \quad o=n e k i-n a j e]=j o$.

then $\quad \operatorname{dog}=$ ERG smell-3A-PAS RELZ 3 ABS=stand-PAS=LOC

'Then the dog smells where it (the frog) had stood.'

\{Trad. narr./'bemo14_'baw\}

In addition, the subordinators of the reason, conditional and before-clauses also show traces of this strategy, but now form a complex reference-tracking device (Vuillermet 2014).

\subsection{Topological specification}

As mentioned above and illustrated in $(36 \mathrm{a}-\mathrm{c})$, the general locative $=j o$ is the most frequent adnominal in the biclausal Source expression. Other spatial adnominals, namely the superessive ='biajje and the perlative $=j j e$, are less frequent and only available in Traj. To describe the video-clip $\{034\}$, two speakers used the general locative (cf. Example (46b)) while two others the more specific superessive in (40a-b). 
(40) a. Towaa-ani, [mei='biajje neki] meshijaji=asijje

jump-Prs stone $=\mathbf{O N}(\mathbf{T O})$ stand sand $=\mathrm{ALL}$

'He's jumping from the top of the rock to the sand.'

\{Traj 034_Sap\}

b. [Mei='biajje neki] towaa-ani.

stone $=\mathbf{O N}$ (TO) stand jump-PRS

'He's jumping from the top of the rock.'

\{Traj 034_Soo\}

The biclausal expression of Source with ='biajje 'on(TO)' in (40) provides the topological relation of the Figure to the Ground: the Source is the top of the rock.

Perlative markers also occur in the biclausal Source expression, but are infrequent and attested with two speakers only, who elsewhere produced regular DCs with a locative (e.g. Example (44)). The Source location seems then more general, i.e. refers to an area rather than to a specific location (cf. the discussion in Section 3.3 and Example (34b)).

(41) a. [Mei-wejja=jje ani]... oya... kwaya-ani.

stone-hole=PERL sit.NF 3ABS go_out-PRS

'She's going out of the cave.' (Lit: sitting in the cave area, she is going out)

\{Traj 023_Zen\}

b. ['Dewe-iye=jje neki] oya kwaya-'io-ani.

bamboo_sp-orchard=PERL stand.NF 3ABS go_out-TEL-PRS

'He is going out of the bamboo-like bush.'

(Lit: standing in the bamboo-bush area, he's going out)

\{Traj 055_Zen\}

This section showed that some semantic granularity reported in the adnominal inventory is available in the biclausal strategy: the specification of the topological relation is equally available for the Source and the Goal in this regard. However, no biclausal expression of [+HUMAN] Sources is attested in my corpus: speakers either left the Source unmentioned or used the transitive verb jiña- 'leave behind', where the Source is the Object of the main verb.

(42) Kwiijji=a jiña-ka-'io-ani e-pona [e-jaa'bicha jaa].

man=ERG leave-3A-TEL-PRS NPF-woman RES-lying_down lie.NF

'The man leaves the woman (lying down) behind.'

\{Traj 035_Sap\}

Semantic asymmetry in the [ \pm HUMAN] feature thus persists.

\subsection{Role(s) of the Posture Verbs}

Kopecka \& Ishibashi (2011:146) suggest that the biclausal Source expression is semantically more specific than a simple adnominal as it specifies the posture of the Figure. However, the PV in Ese Ejja does not always denote the actual posture of the Figure. For instance, in (36c), the woman was standing rather than sitting 
in the cave before exiting it. The PV ani 'sit' was nevertheless used because both female Figures and cave (and house) Grounds are culturally associated with the sitting position.

By contrast, male Figures and field Grounds (and probably forest as well) are associated with the PV neki 'stand' (see Vuillermet 2012a:649-654) for a discussion, and Rumsey 2002 for similar Figure/posture correlates in Papuan languages). Table 10 illustrates the 12 utterances with a Source biclausal construction of the speaker Sapaia: males are consistently associated with 'stand', while women are mostly associated with 'sit', unless the Ground is a field, a Ground typically associated with the standing position. ${ }^{13}$

Table 10. Influence of Figure gender and Ground type in Sapai's answers

\begin{tabular}{|c|c|c|c|c|c|c|c|c|}
\hline & \multicolumn{2}{|c|}{ Cave } & \multicolumn{2}{|c|}{ FOREST } & \multicolumn{2}{|c|}{ Corn Field } & \multicolumn{2}{|c|}{ TOP OF CLIFF } \\
\hline & $\mathrm{Sit}^{\star}$ & Stand & Sit & Stand & Sit & Stand & Sit & Stand \\
\hline Female & 5 & & 1 & & & 1 & & \\
\hline Male & & 1 & & 1 & & & & \\
\hline MaLe (child) & & 2 & & & & & & 1 \\
\hline
\end{tabular}

${ }^{\star}$ Note that the moving Figure is standing in all the videoclips.

A clear illustration of the various roles of the PV come from the utterances in response to Videoclip $\{031\}$, when a young boy runs out of the sea. In (43) (repeated from 36a), the speaker uses jaa 'lie', the posture verb that tends to be associated with fish (but not humans) ${ }^{14}$ in water grounds. Note that jaa 'lie' is also used to refer to the existence of elongated water grounds like rivers (see Vuillermet 2009, 2012a: 629-30).

(43) [Enaojjo=jo jaa] meshi=yasijje neki-sowa-ki-'io-ani

river=LOC lie.NF(.ABS) ground=ALL stand-go_up-GO_TO_V-TEL-PRS

'He is going up from the river to the ground.' $\quad$ Traj 031_Lev ${ }^{15}$

13. The PV seems to indicate the prototypical posture of the Figure when located on the Ground (humans are prototypically working in a standing position when in the field) rather than the prototypical or culturally fixed posture of the Ground itself (or maybe the entities associated with the Ground, e.g. banana trees), which would be much more surprising, but not completely out of question given Examples (43)-(44). More work is required on this issue.

14. As mentioned below, the verb for 'swim' shokwishokwi- is typically conjugated with the present suffix -'ba'e 'float.Prs', not -jaa 'lie.Prs'.

15. This sentence nicely illustrates the complexity of the use of posture verbs in Ese Ejja, as it contains no less that three posture verb roots: jaa 'lie', neki 'stand' and ani 'sit' (here the default 
By contrast, another speaker first uses neki- 'stand' in (44), which corresponds to the real posture of the child going out of the water in the video-clip. He then corrects himself with the PV 'ba'e- 'hang, float', which could refer to the floating posture when swimming (see shokwishokwi-ba'e 'he is swimming (lit. he is swimming-floating) in a Frog Story narrative). It is noteworthy that 'ba'e 'hang; float' is used to refer to the existence of stretched out water Grounds (lakes and seas).

(44) Kwiijji-sho'i [ena=jo neki] neki-sowa-ani, no [ena=jo 'ba'e] man-child water=LOC stand.NF stand-go_up-PRS no(sP) water=LOC float.NF neki-sowa-ki-ani.

stand-go_up-GO_TO_V-PRS

'The boy is going out of the water (lit. Standing vs. Floating in the water, the boy is going out).'

\{Traj 031_Zen\}

Three distinct PVs were thus used to describe the same video-clip, depending on the focus of the speaker: neki 'stand', the real posture of the Figure when running outside the water, 'ba'e 'float', the posture of the boy before running out of the water, or jaa 'lie', the posture typically associated with fish and rivers.

To sum up, the posture verb in the biclausal Source expression does not necessarily give information on the actual posture of the Figure but may be redundant with the gender of the Figure or with the posture typically adopted on a given Ground. Further investigation is required to understand when the actual posture vs. the "culturally associated posture(s)" prevail, and how Grounds really impact on the choice of the PV. The next section highlights the role played by the type of verb in the main clause.

\subsection{Role of the verb type}

This section discusses the impact of the verb in determining the semantics of the DC. Like the polyfunctional adnominals $=k e$ 'HUM.ALL', ='biajje ' $=\mathrm{ON}(\mathrm{Tо})$ ' and =jje 'PERL', biclausal Source expressions acquire their Source reading from the main clause motion verb. If the verb of the main clause is not a motion verb, the biclausal construction has a locative meaning.

In most previous examples, the semantics of the verb of the main clause (kwaya- 'go out' or neki-sowa- 'go up') contribute to the Source interpretation. By contrast, the two examples in (45) show that non-motion verbs in the main clause

present tense marker). Only one, neki- 'stand' refers to the real posture the child has in the videoclip. 
do not trigger a Source reading: the DC indicates the location of the Figure, while combing her hair or drinking water.

(45) Non-motion verb: Location reading (not Source)

a. [Ekipajaajji=jo ani] jja-ja'be-ki-ani-ani.

mat=LOC sit.NF(.ABS) MID-comb-MID-IPFV-PRS

'Sitting on the mat, she is combing her hair.'

\{Traj 019_Vie\}

b. [Ekipawana='biajje ani]=a ena ishi-ka-ani. mat $=\mathrm{ON}(\mathrm{TO}) \quad$ sit.NF=ERG water drink-3A-PRS

'Sitting on the mat, she is drinking water.'

\{Traj 006_Soo\}

With a motion verb like towaa- 'jump', which is a self-contained motion verb, the reading of the dependent clause in a biclausal construction depends on the context.

(46) Self-contained motion verb: ambiguous reading

E-sho'i towaa-ani [kwei-sawa=jo neki].

NPF-child jump-PRS river=LOC stand.NF

'He's jumping on the riverbank.'

Or, in a different context, 'He is jumping from the riverbank.'

\{Traj 075_Sap\}

The reading can be ambiguous with perception verbs like 'watch', where the Figure can be 'standing on the bridge while watching' or be 'watching from the bridge (where he stands).

(47) [Puente='biajje neki]=a eta'a 'ba-ka-ani.

bridge $(\mathrm{SP})=\mathrm{ON}(\mathrm{TO})$ stand.NF $=\mathbf{E R G}$ river watch-3A-PRS

'He is watching the river from a bridge'

(or 'Standing on a bridge, he is watching the river')

$\{$ Traj 047_Vie\}

\subsection{Source vs. non-Source spatial dependent clauses}

As already mentioned in Section 3.2.1, the biclausal strategy is also available to the two other path portions, Goal (e.g., (literally) 'Y moves to [(where) X is]') and Median illustrated in (48a-b). (See also Examples (29a) and (49)) I will call these "non-Source DCs", because they encode the Goal or the Median.

(48) a. E-sho'i kwaya-ani [pia neki]=yasijje.

NPF-child go_out-PRS other stand.NF=ALL

'A child is going out to (where) another one stands.'

\{Traj 030_Vie\} 
b. Owe e-pona jja-ejje-ki-ani puente=jje [kwiijji one NPF-woman MID-cross-MID-PRS bridge(SP)=PERL man neki]=jje. stand.NF=PERL

'A woman is crossing over the bridge, passing by a man standing.'

\{Traj 047_Sap\}

These are not only rare in the Traj corpus ( 4 tokens only vs. 63 tokens for the Source counterpart), ${ }^{16}$ but they differ from the Source DC at both the syntactic and semantic levels.

Source DCs seem to look very much like non-Source DCs described in Section 2 but they differ in many respects. The Source DC is a Basic Locative Construction, while the non-Source DC is not:

i. a Source DC has a Ground argument (and are BLCs), while a non-Source DC has none;

ii. a non-Source DC does not only allow PVs but any verb types, as long as they are marked for an imperfective thanks to a grammaticalized posture verb.

(49) Kwiijji jja-ejje-ki-ani [e-pona=kwana mimi mimi-neki]=jje.

man MID-cross-MID-PRS NPF-woman=PL talk RDP-stand/IPFV.NF=PERL

'A man is passing by (lit. is crossing) women (who stands) talking.'

\{Traj 046_Sap\}

More importantly, a non-Source DC has an independent overt subject, while a Source DC has no overt argument (cf. Section 4.1.2). Unlike the non-Source DC, the Source DC relativizes a core argument of the main clause. The spatial adnominal also has a different scope in Source DCs than in non-Source DCs: it specifies the role of the Ground NP within Source DCs, and within the MC in the case of non-Source DCs.

The biclausal Source expression is not specific to Ese Ejja. It is present in better-known languages like Japanese and Polish, or lesser-known ones like Ye'kwana (Carib) (Kopecka \& Ishibashi 2011: 146). It would be interesting to know how cross-linguistically common PVs are in such biclausal expressions - both Japanese and Polish use PVs while Ye'kwana has no overt predicate. Languages seem to vary a lot in terms of frequency of use. Such biclausal Source expressions

16. I see two main causes for this frequency: (1) a biclausal Source construction is always obligatory if the speaker wants to unambiguously refer to a Source Ground; (2) a biclausal nonSource construction is obligatory only if the speaker wants to refer to a Goal Ground which is "an area around a human entity" (otherwise adnominals can be used). 
are for instance much more common in Ese Ejja than in Polish (Anetta Kopecka, pc August 2017), who has other morphosyntactic devices to express the Source.

\subsection{Summary of the asymmetries in the biclausal Ground expressions}

Syntactically distinct, biclausal Source and non-Source constructions also play distinct roles within the system. Biclausal Goal (and Median) constructions encode a more general location than the allative adnominal =asijje, like an area where a tree stands. In addition, biclausal Goal constructions can encode a [+HUMAN] Ground; unlike the adnominal =ke, they allow to mention the activity of the [+HUMAN] Goal (talking, lying, etc).

Biclausal Source expressions are more informative than the general adnominal =jje 'PERL' in that they only encode the Source. They are also more specific in that they allow one to specify the topological relation with the Source Ground, and, in some cases, the posture of the Figure.

Although the biclausal strategy is available for Goals, the biclausal Source expression is still a case of asymmetry in terms of "event sequencing" (Kopecka \& Ishibashi 2011:145): the overall frequency of the biclausal Source strategy is comparable to that of the adnominal Goal strategy. Such a Source-biased constructional asymmetry is well-attested cross-linguistically. One specificity of the Ese Ejja construction is to involve PVs, even though the PV does not necessarily inform on the actual posture of the Figure.

\section{Conclusions}

The most basic morphosyntactic inventory used to express the different portions of Path and present in the Traj corpus is summarized in Table 11. For the Ground markers available to more than one Path portion, the table distinguishes between the prototypical and the less frequent meanings. Table 12 summarizes the various types of (a)symmetries found in Ese Ejja.

Table 11. Distribution of the Ground markers (excluding topologically specific ones)

\begin{tabular}{|c|c|c|c|c|c|c|}
\hline & $\begin{array}{l}=\text { =jo } \\
\text { 'LOC' }\end{array}$ & $\begin{array}{l}=\text { asijje } \\
\text { 'ALL' }\end{array}$ & $\begin{array}{l}=k e \\
\text { 'HUM.ALL' }\end{array}$ & $\begin{array}{l}=j j e \\
\text { 'PERL' }\end{array}$ & $\begin{array}{l}\text { biclausal } \\
\text { source exp. }\end{array}$ & \multirow{5}{*}{$\begin{array}{l}\text { prototypical } \\
\text { meaning } \\
\text { attested but less } \\
\text { frequent meaning }\end{array}$} \\
\hline LOCATIOI & & & & & & \\
\hline GOAL & & & & & & \\
\hline MEDIUM & & & & & & \\
\hline SOURCE & & & & & & \\
\hline
\end{tabular}


Table 12. Summary of the asymmetries in Ese Ejja

\begin{tabular}{|c|c|c|c|c|c|}
\hline & \multicolumn{4}{|c|}{ ADNOMINAL MORPHOLOGY } & \multirow{2}{*}{$\begin{array}{c}\text { MORPHOSYNTAX } \\
\text { BICLAUSAL } \\
\text { CONSTRUCTIONS }\end{array}$} \\
\hline & $\begin{array}{l}\text { \# of MARKERS } \\
\text { AVAILABLE IN } \\
\text { Traj }\end{array}$ & $\begin{array}{l}\text { DEDiCATED } \\
\text { SEMANTICS }\end{array}$ & $\begin{array}{c}{[ \pm] \text { HUMAN }} \\
\text { DISTINCTION }\end{array}$ & $\begin{array}{l}\text { TOPOLOGICAL } \\
\text { RELATIONS }\end{array}$ & \\
\hline GOAL & 4 & 1 & $\checkmark$ & $\begin{array}{c}\checkmark \\
\text { (at least 3) }\end{array}$ & $\begin{array}{c}\text { infrequent } \\
\text { (express a more } \\
\text { general Goal) }\end{array}$ \\
\hline SOURCE & $\begin{array}{c}1 \text { (primarily } \\
\text { Median) }\end{array}$ & o & - & - & most frequent \\
\hline
\end{tabular}

The Goal-biased asymmetries concern the morphological inventory and the morphological complexity: Ese Ejja counts more Goal(/Location) than Source(/Median) adnominals, and only Goal has one dedicated adnominal (as well as Location). Only Goal/Location have a specific adnominal to refer to a [+HUMAN] Ground. In addition, Goal-biased asymmetry exists at the syntactic level: the most frequent Source expression is a biclausal construction. Overall, the expression of Goal is more specific, distinguishes between [ \pm HUMAN], and tends to be morphosyntactically more concise.

Interestingly, the dedicated Goal adnominal in Ese Ejja contradicts observed crosslinguistic tendencies in being historically more complex than the (Median-)Source marker. However, the unexpected complexity results from a recent innovation, absent from the sister languages.

As a last remark, Ese Ejja data seem to call attention to the role of the Median in the system, which is particularly polysemous in this language, and, more generally, to the absence vs. presence of dedicated markers. Apart from the dedicated Goal adnominal and the biclausal expression of Source, the Ese Ejja resources are often polyfunctional (cf. Table 11). Median seems to play an important role in Ese Ejja because of its synchronic polysemy, plausibly caused by diachronic changes. The Ese Ejja system probably used to display two markers for Location and Goal (one general and one specific, as in all sister languages) on the one hand, and one marker for Median and Source in the other, and it evolved into a system with one dedicated Goal marker and a dedicated Source construction. This raises methodological and theoretical issues about the correlates between SourceGoal asymmetry and the rest of the system. For instance, how should one account for Source-Goal (a)symmetries at the morphosyntactic level in languages with no dedicated resources (e.g. when Location and Goal, or Source and Median, are expressed with a single marker)? How do languages deal with the third portion of Path, namely the Median? For instance, are the rare Source-Goal symmet- 
ric systems also symmetric with regard to the Median? Does Source-Median or even Goal-Median symmetry exist in languages otherwise displaying asymmetric Source-Goal systems? These interesting issues remain to be investigated in the future in more detail.

\section{Funding}

Fieldwork for this research has been supported by an ELDP grant FTGo116 and the paper was written and finalized during two postdoctoral fellowships, from the Radboud Excellence Initiative of the Radboud Universiteit and from the LABEX ASLAN (ANR-10-LABX-oo81) of the Université de Lyon within the program "Investissements d'Avenir" (ANR-11-IDEX-ooo7).

\section{Acknowledgements}

My thanks go to the Ese Ejja people, and especially to my hosts/friends/family Inotawa, 'Dejja'oshe and all their (grand)children and to the nine consultants who described the visual stimuli set Trajectoire. I would also like to thank Miyuki Ishibashi and Anetta Kopecka, and two anonymous reviewers, for helpful feedback on earlier versions of this article that have led to substantial revision and improvement.

\section{Abbreviations}

$\begin{array}{llll}\text { A } & \text { agent-like argument } & \text { MID } & \text { middle } \\ \text { ABL } & \text { ablative } & \text { NF } & \text { nonfinite } \\ \text { ABS } & \text { absolutive } & \text { NPF } & \text { noun prefix } \\ \text { ADJV } & \text { adjectivizer } & \text { PERL } & \text { perlative } \\ \text { ALL } & \text { allative } & \text { PL } & \text { plural } \\ \text { APF } & \text { adjective prefix } & \text { PROH } & \text { prohibitive } \\ \text { BCL } & \text { basic locative construction } & \text { PRS } & \text { present } \\ \text { CONT } & \text { continuous } & \text { PST } & \text { past } \\ \text { DC } & \text { dependent clause } & \text { PV } & \text { posture verb } \\ \text { DEM } & \text { demonstrative } & \text { RDP } & \text { reduplication } \\ \text { DO } & \text { '(to) do' Associated Motion verb } & \text { RELZ } & \text { relativizer } \\ \text { ERG } & \text { ergative } & \text { REM } & \text { remote past } \\ \text { EXCL } & \text { exclusive } & \text { REP } & \text { reportative } \\ \text { FUT } & \text { future } & \text { RES } & \text { resultative } \\ \text { GEN } & \text { genitive } & \text { SG } & \text { singular } \\ \text { HUM } & \text { human } & \text { SML } & \text { similative } \\ \text { INTS } & \text { intensifier } & \text { (SP) } & \text { Spanish loanword } \\ \text { IPFV } & \text { imperfective } & \text { SP } & \text { species } \\ \text { LOC } & \text { locative } & \text { SUPER } & \text { superessive } \\ \text { MC } & \text { main clause } & \text { TEL } & \text { telic }\end{array}$




\section{References}

Aurnague, Michel. 2004. Les Structures de l'espace linguistique: Regards croisés sur quelques constructions spatiales $d u$ basque et du français (Bibliothèque de l'Information Grammaticale 56). Louvain/Dudley, Ma: Peeters.

Aurnague, Michel, Laure Vieu \& André Borillo. 1997. Représentation formelle des concepts spatiaux dans la langue. In Michel Denis (ed.), Langage et cognition spatiale, 69-102. Paris: Masson.

Bourdin, Philippe. 1997. On Goal-Bias across languages: Modal, configurational and orientational parameters. Palek, Bohumil (ed.), Proceedings of LP '96: Typology: prototypes, item orderings and universals, proceedings of the conference held in Prague, August 20-22, 1996, 185-216. Prague: Charles University Press.

Bowerman, Melissa \& Eric Pederson. 1992. Topological relations picture series. In Stephen C. Levinson (ed.), Space stimuli kit 1.2: November 1992. Nijmegen: Max Planck Institute for Psycholinguistics. Online publication available at: http://fieldmanuals.mpi.nl /volumes/1992/bowped/ (Last access 26 March 2020).

Emkow, Carola. 2006. A Grammar of Araona, an Amazonian Language of Northwestern Bolivia. Melbourne: La Trobe University PhD dissertation.

Freeman, Norman H., Cristopher G. Sinha \& Jacqueline A. Stedmon. 1981. The allative bias in three-year-olds is almost proof against task naturalness. Journal of Child Language 8(2): 283-96. https://doi.org/10.1017/S0305000900003196

Grinevald, Colette. 2011. On constructing a working typology of the expression of PATH. Les Cahiers de Faits de Langues 3. 43-70. https://doi.org/10.1163/19589514-038-02-900000005

Guillaume, Antoine. 2008. A grammar of Cavineña (Mouton Grammar Library 44). Berlin/New York: de Gruyter. https://doi.org/10.1515/9783110211771

Guillaume, Antoine. 2012. Maropa (Reyesano). In Mily Crevels \& Peter Muysken (eds.), Las lenguas de Bolivia, 191-229. La Paz: Plural Editores.

Guillaume, Antoine. 2014. El idioma Takana. Esbozo de su fonología y su gramática. Unpublished manuscript.

Guillaume, Antoine. 2016. Associated motion in South America: Typological and areal perspectives. Linguistic Typology 20(1). 81-177. https://doi.org/10.1515/lingty-2016-0003

Hagège, Claude. 2010. Adpositions. Oxford: Oxford University Press. https://doi.org/10.1093/acprof:oso/9780199575008.001.0001

Heine, Bernard \& Tania Kuteva. 2002. World lexicon of grammaticalization. Cambridge: Cambridge University Press. https://doi.org/10.1017/CBO9780511613463

Henrich, Joseph, Steven J. Heine \& Ara Norenzayan. 2010. The weirdest people in the world? Behavioral and Brain Sciences 33(2-3). 61-83. https://doi.org/10.1017/S0140525X0999152X

Ihara, Hiroko \& Ikuyo Fujita. 200o. A cognitive approach to errors in case marking in Japanese agrammatism: The priority of the Goal - ni over the Source - kara. In Ad Foolen \& Frederike van der Leek (eds.), Constructions in cognitive linguistics (Current issues in linguistic theory 178), 123. Amsterdam/Philadelphia: John Benjamins. https://doi.org/10.1075/cilt.178.o9iha

Ikegami, Yoshihiko. 1987. 'Source' vs 'Goal': A case of linguistic dissymmetry. In René Dirven \& Günter Radden (eds.) Concepts of case, 122-46. Tübingen: Günter Narr Verlag. 
Ishibashi, Miyuki. 2015. A field method to describe spontaneous motion events in Japanese. Proceedings of the Annual Meeting of the Berkeley Linguistics Society 41. 197-218. https://doi.org/10.20354/B4414110006

Ishibashi, Miyuki, Anetta Kopecka \& Marine Vuillermet. 2006. Trajectoire: Matériel visuel pour élicitation des données linguistiques. Laboratoire Dynamique du Langage, CNRS / Université Lyon 2. Projet de Fédération de recherche en Typologie et Universaux Linguistiques. http://tulquest.huma-num.fr/fr/node/132

Kopecka, Anetta. 2009. L’expression du déplacement en français: l'interaction des facteurs sémantiques, aspectuels et pragmatiques dans la construction du sens spatial. Langages 173(1). 54-75. https://doi.org/10.3917/lang.173.0054

Kopecka, Anetta \& Miyuki Ishibashi. 2010. Guide de travail pour l'axe 'Asymétrie'. Projet “Trajectoire." Laboratoire Dynamique Du langage (CNRS / Université Lyon 2) Fédération de Recherche en Typologie et Universaux Linguistiques, CNRS, France.

Kopecka, Anetta \& Miyuki Ishibashi. 2011. L'(a)symétrie dans l'expression de la source et du but: perspective translinguistique. Les Cahiers de Faits de Langues 3. 131-49. https://doi.org/10.1163/19589514-038-02-900000009

Kutscher, Silvia. 2010. When 'towards' means 'away from': The case of directional-ablative syncretism in the Ardeşen variety of Laz (South-Caucasian). STUF - Language Typology and Universals 63(3). 252-271. https://doi.org/10.1524/stuf.2010.0021

Lakusta, Laura \& Barbara Landau. 2005. Starting at the end: The importance of goals in spatial language. Cognition 96(1). 1-33. https://doi.org/10.1016/j.cognition.2004.03.009

Levinson, Stephen C. 2003. Space in language and cognition: Explorations in cognitive diversity (Language, Culture, and Cognition 5). Cambridge/New York: Cambridge University Press. https://doi.org/10.1017/CBO9780511613609

Mayer, Mercer. 1969. Frog, where are you? New York: Dial Books.

Nikitina, Tatiana. 2009. Subcategorization pattern and lexical meaning of motion verbs: A study of the Source/Goal ambiguity. Linguistics 47(5). 1113-41. https://doi.org/10.1515/LING.2009.039

Papahagi, Cristiana. 2011. Pour une typologie des systèmes d’adnominaux de La Trajectoire. Les Cahiers de Faits de Langues 3. 117-30. https://doi.org/10.1163/19589514-038-02-900000008

Regier, Terry \& Mingyu Zheng. 2007. Attention to endpoints: A cross-linguistic constraint on spatial meaning. Cognitive Science 31(4). 705-19. https://doi.org/10.1080/15326900701399954

Rumsey, Alan. 2002. Men stand, women sit: On the grammaticalization of posture verbs in Papuan languages, its bodily basis and cultural correlates. In John Newman (ed.), The linguistics of sitting, standing, and lying (Typological Studies in Language 51), 179-211. Amsterdam/Philadelphia: John Benjamins. https://doi.org/10.1075/tsl.51.ogrum

Stefanowitsch, Anatol \& Ada Rohde. 2004. The goal bias in the encoding of motion events. In Günter Radden \& Klaus-Uwe Panther (eds.), Studies in linguistic motivation, 249-267. Berlin/New York: de Gruyter.

Talmy, Leonard. 2000. Toward a cognitive semantics: Typology and process in concept structuring. Cambridge, MA: MIT Press.

Vuillermet, Marine. 2009. Los verbos de postura Ese Ejja no se quedan inmóviles. Y a veces se desvían. Proceedings of the Conference on Indigenous Languages of Latin America-IV, 1-20. Austin, Texas: https://ailla.utexas.org/sites/default/files/documents/Vuillermet _CILLA_IV.pdf (Last access: 26 March 2020) 
Vuillermet, Marine. 2012a. A grammar of Ese Ejja, a Takanan language of the Bolivian Amazon. Lyon: Université Lumière Lyon $2 \mathrm{PhD}$ dissertation.

Vuillermet, Marine. 2012b. Une typologie en cheminement: Contribution de l'ese ejja à l'étude du mouvement associé. LIDIL 46. 79-100. Available at: https://journals.openedition.org /lidil/3244?lang=en (Last access: 26 March 2020).

Vuillermet, Marine. 2013. Dónde, cuándo, y con quién ocurren acciones: El movimiento asociado en Ese Ejja. In Ana María Ospina-Bozzi (ed.), Expresión de nociones espaciales en lenguas Amazónicas, 33-53. Bogota: Universidad Nacional de Colombia e Instituto Caro y Cuervo.

Vuillermet, Marine. 2014. The multiple co-reference systems in the Ese Ejja subordinate clauses. In Rik van Gign, Jeremy Hammond, Saskia van Putten, \& Ana Vilacy Galucio (eds.), Information structure and reference tracking in complex sentences (Typological Studies in Language 105), 341-71. Amsterdam/Philadelphia: John Benjamins. https://doi.org/10.1075/tsl.105.12vui

Vuillermet, Marine. 2015. The allative in Ese'eja: grammaticalization or homophony? presented at the Workshop on Newly identified paths of grammaticalization in Meso- and South American language, Radboud Universiteit, Nijmegen, The Netherlands, September 28, 2015.

Vuillermet, Marine. 2018. Documentation of the Ese Ejja language of the Amazonian region of Bolivia. London: SOAS, Endangered Languages Archive. https://elar.soas.ac.uk /Collection/MPI1029726 (Last access: 23 March 2020)

Vuillermet, Marine \& Anetta Kopecka. 2019. Trajectoire: a methodological tool for eliciting path of motion. In Aimée Lahaussois \& Marine Vuillermet (eds.), Methodological tools for linguistic description and typology (Special Publication No. 16 of Language Documentation \& Conservation ), 97-123. 


\section{Appendix}

Table 13. Ese Ejja participants in Traj, relevant sociolinguistic information and version watched.

\begin{tabular}{|c|c|c|c|c|c|c|c|}
\hline & $\begin{array}{l}\text { Participant } \\
\text { names }\end{array}$ & $\begin{array}{l}\text { Sonene } \\
\text { variant }\end{array}$ & $\begin{array}{l}\text { Madidi } \\
\text { variant }\end{array}$ & Community & Age & Gender & Version \\
\hline Eli & $\begin{array}{l}\text { Elico Ortiz } \\
\text { Callaú }\end{array}$ & $\mathrm{x}$ & & Genechiquía & 52 & M & $\mathrm{V}_{2}$ \\
\hline Lev & $\begin{array}{l}\text { Levitico Santa } \\
\text { Cruz Tirina }\end{array}$ & $\mathrm{x}$ & & Genechiquía & 20 & M & $\mathrm{V}_{2}$ \\
\hline Sil & $\begin{array}{l}\text { Silavia Ortiz } \\
\text { Monasterio }\end{array}$ & $\mathrm{x}$ & & Genechiquía & 27 & $\mathrm{~F}$ & $\mathrm{~V}_{3}$ \\
\hline Zen & $\begin{array}{l}\text { Zenon Yojajé } \\
\text { Ekinei }\end{array}$ & $\mathrm{x}$ & & Palmareal & $? 25$ & M & $\mathrm{V}_{3}$ \\
\hline Nil & $\begin{array}{l}\text { Nilson Chavez } \\
\text { Gonzales }\end{array}$ & & $\mathrm{x}$ & Port. Bajo & 28 & M & $\mathrm{V}_{2}$ \\
\hline Sap & $\begin{array}{l}\text { Javier Monje } \\
\text { Santa Cruz }\end{array}$ & & $\mathrm{x}$ & Port. Bajo & 25 & M & $\mathrm{V}_{1}$ \\
\hline Soo & $\begin{array}{l}\text { Florentina Callaú } \\
\text { Varga }\end{array}$ & & $\mathrm{x}$ & Port. Bajo & 38 & $\mathrm{~F}$ & $\mathrm{~V}_{3}$ \\
\hline Mil & $\begin{array}{l}\text { Milton Gamez } \\
\text { Moreno }\end{array}$ & & $\mathrm{x}$ & Eiyoki’bo & 28 & M & $\mathrm{V}_{3}$ \\
\hline Vie & $\begin{array}{l}\text { Gilberto Torres } \\
\text { Gamez }\end{array}$ & & $\mathrm{x}$ & Eiyoki'bo & 28 & M & $\mathrm{V}_{1}$ \\
\hline \multicolumn{2}{|c|}{ TOTAL / AVERAgE } & 4 & 5 & & 30 & $\begin{array}{l}2 \mathrm{~F} / \\
7 \mathrm{M}\end{array}$ & $\begin{array}{l}2 V_{1} \\
3 V_{2} \\
4 V_{3}\end{array}$ \\
\hline
\end{tabular}


Table 14. Explicit Ground encoding by speaker.

\begin{tabular}{|c|c|c|c|c|c|c|c|c|c|c|}
\hline & & ALL & $\begin{array}{l}\text { MEDian / } \\
\text { SourCE }\end{array}$ & $\begin{array}{c}\text { SOURCE } \\
\text { ONLY }\end{array}$ & & $\begin{array}{l}\text { Socio } \\
\text { infor }\end{array}$ & $\begin{array}{l}\text { lingui } \\
\text { cmatic }\end{array}$ & $\begin{array}{l}\text { stic } \\
\text { on }\end{array}$ & & Remarks \\
\hline & 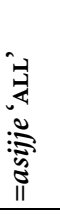 & 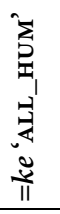 & 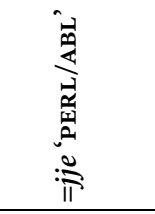 & 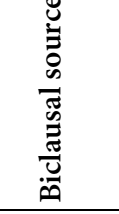 & 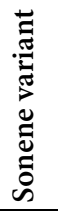 & 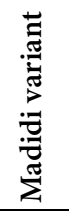 & $\begin{array}{l}\stackrel{\vec{E}}{\Xi} \\
\Xi \\
\Xi \\
0 \\
0\end{array}$ & $\overbrace{4}^{\circ}$ & 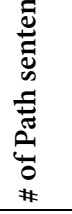 & \\
\hline Eli & 1 & o & 2 & 0 & $\mathrm{x}$ & & $\mathrm{Ge}$ & 52 & 55 & Almost no Ground \\
\hline Lev & 12 & 1 & 11 & 14 & $\mathrm{x}$ & & $\mathrm{Ge}$ & 20 & 55 & \\
\hline Sil & 4 & 1 & 12 & 1 & $\mathrm{x}$ & & $\mathrm{Ge}$ & 27 & 44 & Fewer utterances \\
\hline Zen & 17 & o & 15 & 13 & $\mathrm{x}$ & & $\mathrm{Pa}$ & $? 25$ & 55 & \\
\hline Nil & 12 & 0 & 7 & 10 & & $\mathrm{x}$ & $\mathrm{PB}$ & 28 & 55 & \\
\hline Sap & 11 & 1 & 8 & 12 & & $\mathrm{x}$ & $\mathrm{PB}$ & 25 & 55 & \\
\hline Soo & 15 & 1 & 14 & 6 & & $\mathrm{x}$ & $\mathrm{PB}$ & 38 & 55 & \\
\hline Mil & 2 & o & 3 & o & & $\mathrm{x}$ & $\mathrm{E}$ & 28 & 48 & $\begin{array}{l}\text { Almost no Ground \& } \\
\text { fewer utterances }\end{array}$ \\
\hline Vie & 4 & o & 19 & 5 & & $\mathrm{x}$ & $\mathrm{E}$ & 28 & 55 & \\
\hline Total & 78 & 4 & 91 & 61 & & & & & 477 & \\
\hline
\end{tabular}

\section{Address for correspondence}

Marine Vuillermet

Institut für Vergleichende Sprachwissenschaft

Center for the Interdisciplinary Study of Language Evolution

Universität Zürich

Plattenstrasse 54

CH-8032 Zürich

Europe

marine.vuillermet@uzh.ch

Dhttps://orcid.org/oooo-ooo2-6443-8461 


\section{Publication history}

Date received: 20 April 2018

Date accepted: 5 June 2020

Published online: 22 December 2020 